\title{
LEGAL PROTECTION OF ULAYAT RIGHTS
}

\author{
Ramiah Lubis, ${ }^{1}$ Hijriyana Safithri ${ }^{2}$
}

\begin{abstract}
Land is the surface of the earth which is one of the objects regulated by Agrarian Law. The new Agrarian Law must comply with the legal awareness of the people at large. Because the Indonesian people are largely subject to customary law, the new agrarian law will also be based on the provisions of customary law as original law, which are refined and adjusted to the interests of the community. Customary law is the main source in the formulation of national land laws, as the first source. In the land law, the hierarchy of land tenure rights is regulated, including the Ulayat Rights. The method used in this research is field research. Writing this research aims to describe the application of the distribution of customary land rights owned by the customary law community of the MuaraEnim district, namely Paya Angus Village and the form of legal protection for the indigenous people of Paya Angus, but because their work does not reside in Paya Angus Village. The result of this research is that the residents of Paya Angus village have obtained their customary rights in accordance with the regulations in force in the village and the form of legal protection obtained by the residents of Paya Angus village who live outside the village because they work in MuaraEnim district is not clearly explained about There is a legal basis and rules that regulate, but customary rights are recognized by law and its application refers to the Basic Agrarian Law and customary law in force in Paya Angus Village so that with an agreement from the village head, the community is still entitled to get rights. Ulayat and obliged to continuously cultivate the land
\end{abstract}

Keywords: Customary Rights, Indigenous Peoples, Legal Protection

\section{The Introduction}

The state of Indonesia where the land has a function for the prosperity and welfare of its people. The wealth of indigenous peoples is communal land. The position of customary rights is regulated in Article 18B paragraph (2) of the IV amendment of the 1945 Constitution, and under Article 3 of Law Number 5 of 1960 concerning the Basic Agrarian Law, that customary rights and similar rights belong to legal communities. adat, insofar as it still exists, must be in such a way that it is in accordance with the national and state interests, which are based on national unity and must not conflict with laws and other higher regulations. Constitutionally, the guarantee of customary law for the survival of indigenous peoples and their existence is always questionable. Territorial boundaries of customary rights of customary communities cannot be determined with certainty and land as an economic right of every person or legal entity creates conflicts or disputes over ulayat land.

$\begin{array}{llllll}\text { Fakultas Syariah dan Hukum UIN } & \text { Raden } & \text { Fatah } & \text { Palembang, } \\ \text { Email:ramiahlubis_uin@radenfatah.ac.id } & & & \\ \text { Fakultas Syariah dan Hukum UIN } & \text { Raden } & \text { Fatah } & \text { Palembang, } \\ \text { Email:hijriyanasafithri_uin@radenfatah.ac.id } & & & \end{array}$


Land is the surface of the earth which is one of the objects regulated by Agrarian Law. Land governed by agrarian law is not land in its various aspects, but land from its juridical aspect, which is directly related to land rights which are part of the surface of the earth as regulated in Article 4 paragraph (1) of the Basic Agrarian Law (UUPA) (Arba, 2017: 7).

According to SoediknoMertokusumo, Agrarian Law is the whole legal principles, both written and unwritten, which govern agrarian affairs (Mertokusumo, 1988: 12). Bachsan Mustofa explained that the written rule of law is Agrarian Law in the form of Laws and other written regulations made by the State, while the unwritten legal rule is agrarian law in the form of agrarian customary law made by the local customary law community and which growing and developing, and maintaining the effectiveness of the indigenous peoples concerned (Mustofa, 1988: 11).

Land is one of the most important sources of life for humans, whether it functions as a means of making a living as a livelihood in various fields such as agriculture, plantation, animal husbandry, fishery, industry, or used as a place to live.

In the Land Law, the term "land" is used in a juridical sense, as a definition that has been legally defined by the Basic Agrarian Law (UUPA). Article 4 states that on the basis of the State's right to control as referred to in Article 2, it is determined that various rights over the surface of the earth, which are called land, can be given to and owned by persons, individually or collectively. other people as well as legal entities.Land in a juridical sense is the surface of the earth (paragraph 1) of the Basic Agrarian Law, while land rights are the rights to a certain portion of the earth's surface, which is bounded, has two dimensions with length and width (Harsono, 1999: 18).

The juridical provisions regulating the importance of land are contained in Law Number 5 of 1960 concerning Basic Agrarian Basic Regulations (hereinafter referred to as UUPA), which is the implementation of the provisions of Article 33 paragraph (3) of the 1945 Constitution which states "that earth and water and natural resources contained therein shall be controlled by the state and used for the greatest prosperity of the people.

As for further information regarding land law, many are scattered in various other laws and regulations such as Government Regulation Number 40 of 1996 concerning Business Use Rights, Building Use Rights, and Land Use Rights; Regulation of the Minister of Agrarian Affairs / Head of the National Land Agency Number 3 of 1999 concerning Delegation of Authority to Grant and Cancellation of Decisions on Granting Land Rights; and others.

Land is given to a person and is owned by a person with rights as stated in the Basic Agrarian Law, which is to be used or utilized by that person. The granting and possession of land with these rights will be meaningless if its use is limited to land as the surface of the earth or a place to live in. For whatever purposes it is inevitable, it is also necessary to use part of the earth's body underneath and the water and space above it. Therefore in paragraph (2) it is stated that the right to land not only gives the authority to use a certain part of the surface of the earth concerned, which is called "land", but also the earth's body underneath it and the water and space on it (Harsono, 1999: 18).

In the Land Law, States which use what is called the "Accessie Principle" or "the principle of attachment", buildings and plants that are on 
and constitute an integral part of the land are "part" of the land concerned. So, the right to land automatically, by law, also includes ownership of buildings and plants on the land that is entitled, unless there is another agreement with the party who built or planted it.

Generally, the buildings and plants that are on the ground belong to the land owner. However, our land law uses the principle of customary land law which is called the principle of horizontal separation (in Dutch it is called "horizontalescheiding." Buildings and plants are not part of the land. So land rights do not necessarily include ownership of buildings and plants on them (Harsono, 1999: 20).

Legal actions regarding land do not necessarily include buildings and plants belonging to the owner of the land that is on them. If the legal act is intended to include the building and plants, then it must be clearly stated in a deed which proves that the legal act concerned was committed. Whether it is a legal act that covers the land only or only covers buildings or plants on the land.

From legal actions regarding land, of course there will also be there who is the subject of the land who is the ruler of the land. Juridical control is based on rights, which are protected by law and generally give rights holders the authority to physically control the land they are entitled to (Harsono, 1999: 23).

In each land law, there are regulations regarding various tenure rights over land. The Basic Agrarian Law (UUPA) regulates and at the same time stipulates the hierarchy of land tenure rights in our National Land Law, namely: (Harsono, 1999: 24).

1. The right of the Indonesian nation as mentioned in article 1 , as the highest land tenure right, with civil and public aspects;

2. The right to control of the State as mentioned in article 2, solely has the public aspect;

3. The customary rights of indigenous peoples as mentioned in article 3 , have civil and public aspects.

a. Individual rights/individuals, all with a civil perspective, consisting of:Rights to land as individual rights, all of which are directly or indirectly derived from the Rights of the Nation, which are mentioned in article 16 and 53;

b. Waqf, namely property rights that have been donated by article 49

c. Security rights over land which are called "Mortgage Rights" in articles 25, 33, 39 and 51.

Prior to the enactment of the UUPA, one of the Agrarian Laws in the Dutch East Indies (Indonesia) was the enactment of the Customary Agrarian Law, which is the whole of the principles of agrarian law which are derived from customary law and apply to lands owned with regulated land rights. by Customary Law, hereinafter often referred to as customary land or Indonesian land (Santoso, 2012: 7).

Customary law communities also recognize the existence of customary rights. HakUlayat is a series of powers and obligations of certain customary law communities over a certain area which is their ulayat, as the "lebensraum" for its citizens to take advantage of natural resources, including land in the area (Arba, 2017: 95). 
In the customary law community in the territory of the State of Indonesia there are various customary rights, each of which has a different name. As for the names of the ulayat rights as follows: Ambon knows land rights, in Kalimantan it is called Panyampeto, in Java it is known as wewengkon, in Bali it is known as prabumian. In Lombok it is known as Tanah Paer and in MinangKabau "Ulayat" (Arba, 2017: 96).

In the context of the relationship between customary law communities and their territory (ulayat), or in legal reasoning as the relationship between customary law communities as legal subjects of customary rights, understanding the typology of customary law communities is important. Classifying this customary law community is based on the character of their control over the territory or ulayat of the customary law community. Although the classification may not all be used as examples at this time, it is sufficient to provide an overview of what is meant by customary law communities.

Customary law regarding land has a special position in the UUPA, because most Indonesian people adhere to customary law so that customary law is the basis for the formation of the National Land Law. Land law is a system of independent legal branches that govern the juridical aspects of land, which are called land tenure rights. The legal provisions governing land tenure rights can be compiled into one unit which forms one system (Harsono, 2008: 17).

The legality of the customary rights of indigenous peoples has been recognized in article 5 of the UUPA, namely the Agrarian Law which applies to land, water and space, is customary law "as long as it does not conflict with national and State interests, which are based on national unity and Indonesian socialism and with regulations. stated in this Law and with other regulations". Everything with heed the elements that rely on religious law. However, in practice, people still lack legal protection when dealing with development interests.

The provisions that regulate this make customary law a basis for forming. Customary Law is the main basis for the formation of the National Agrarian Law which can be concluded in the Preamble of the UUPA which states "that in relation to what is mentioned in the considerations there is a need for a National Agrarian Law, which is based on customary law on land, which is simple, and guarantees legal certainty for all Indonesian people without neglecting the elements that rely on religious law" (Santoso, 2010:5).

The UUPA states that the national land law is based on customary law. This statement can be found, among others; General explanation number III (1); Article 5 and its explanations.

In the General Explanation point III (1) UUPA states that: Naturally, the new Agrarian Law must comply with the legal awareness of the people at large. Because the Indonesian people are largely subject to customary law, the new agrarian law will also be based on the provisions of customary law as original law, which is refined and adapted to the interests of the people in a modern country and in relation to the international world and adapted to the Indonesian socialism. As it is understood, customary law in its growth cannot be separated from the influence of politics and colonial society which is capitalist and self-governing feudal society. 
In the General Explanation number III (1) of the UUPA above, Article 5 states that; "Agrarian law which applies to the earth, water and space is customary law, as long as it does not conflict with the national and state interests, which is based on national unity, with Indonesian socialism and with other regulations, everything with due regard to the elements that rely on religious law. Customary law, which is the main source in the formulation of national land laws, makes everything from the basic framework of customary law the first source. The new Land Law which was formed using materials from customary law, in the form of legal norms as outlined in statutory regulations as written law, constitutes positive written national land law. LoGA is the first result."

Ulayat land is a plot of land on which there are ulayat rights of a certain customary law community. Ulayat rights are authorities, which according to customary law, are owned by the customary law community over certain areas which are the environment of their citizens, where this authority allows the community to take advantage of natural resources, including land, in the area for their survival. The community and resources in question have a hereditary and inward relationship between the customary law community and the area concerned.

1. In customary rights, there are several characteristics that distinguish it from other rights, namely:

2. 1. Only the legal association of the villagers themselves and their residents. Those who have the right to freely use the illegal lands in their territory.

3. 2. Outsiders may only use the land with the permission of the ruler of the legal association.

4. 3. Members of a legal association may take advantage of the territory of ancient rights provided that it is only for their own families.

5. 4. The legal community is responsible for everything that happens in its territory.

6. 5. Primitive rights cannot be released, transferred, exiled.

7. 6. Ulayat rights include land that has been cultivated, which is covered by individual rights (Muhammad, 1983, 116).

In the application process customary rights have a system, namely:

1. The burial system is joint ownership with the division of the period of arable land.

2. Matokgalengjelirwong is cultivated land divided into several fixed fields.

3. Matokgalengmatokwong is a farmer with changing parts and some parts but the land is controlled for the rest of his life.

4. Land can be inherited along with the acquisition of land that is controlled for life (Wignjodipoero, 1984, 19.

The customary land of the customary community is a form of customary community legal territory whose ownership is controlled by a group of tribes who inhabit a certain area. As in MuaraEnim district, South Sumatra Province in one of the villages, namely Payongus village. This village still applies the distribution of customary land to the local village community. Each head of the family received a communal land distribution.

Paya Angus Village is located in the sub-district of Voorame, MuaraEnim Regency, South Sumatra Province. The people of Paya Angus 
village still use customary law in determining their customary land so that the people there get their rights in land tenure. The land is used for the cultivation of rubber and oil palm plantations because the livelihoods of these residents are rubber and oil palm farmers. However, in practice, is it true that all communities have obtained their Ulayat rights in accordance with customary law which is the main source in the formulation of national land laws.

The distribution of customary land to ulayat rights in the payaangus village is given to each head of the family for the indigenous people of the local village. The communal land is used by the village community for gardening. On a daily basis, the average villager works as a farmer, some also plant rubber and oil palm. There are residents who cultivate their own rubber gardens by cultivating and tapping the rubber themselves or by other people. For oil palm plantations, there are companies involved in managing it, of course, with a profit sharing system between the villagers and the company.

The understanding and views of indigenous peoples on land, especially the Paya Angus Village Community, are supported in the sense of Customary Land Law contained in the Basic Agrarian Law (UUPA), which regulates the control of Land Rights over the Ulayat Rights of the Panyoangus Village Community, so that land rights adat can be fought for through the right legal channels if there are rights to customary land whose acquisition is not in accordance with the rights of indigenous peoples.

In the customary law community in Paya Angus village, do all community members have their customary rights in accordance with the applicable customary rules, what form of legal protection for villagers as residents of Paya Angus Village who live outside Paya Angus village because they work elsewhere is they still get their customary rights. From the description above, the authors are interested in conducting a study entitled Legal Protection of Customary Rights (Study in Paya Angus Village, MuaraEnim Regency).

\section{Research methods}

The method is the procedure for a series of scientific activities in the context of solving a problem that is used to achieve certain goals. This method is used to explain and give conclusions from the object of discussion in a directed manner. This research is a qualitative research with a descriptivequalitative approach. In this study, after the researcher collected data in the form of interviews, documentation, and observations, the data would then be analyzed in more depth so as to form a scientific-natural conclusion that could be accepted by various groups.

Several reasons for choosing this method, namely: first, adjusting this method is easier when dealing with multiple (complex/heterogeneous) realities. Second, this method directly presents the nature of the relationship between researchers and informants. And third, this method is more sensitive and can adapt to a lot of sharpening the joint influence on the value patterns faced (Moleong, 2004: 10).

In the research the interviewed informants were the head of Paya Angus village, village officials and also 5 people from Paya Angus village who had received customary rights from people who work as farmers and who also work as Civil Servants. 


\section{Discussion and Results}

\section{Application of the customary rights of the customary law community of Paya Angus Village, MuaraEnim Regency}

Land is something that is very important for human life, because on this land humans can continue to live to build a place to live or grow crops to continue their life until the future, even after death humans still need land as their last place of life. Human life cannot be separated from the land because it is a source of life in the order of life from traditional times to modern times (Yusuf: 675).

Ulayat land is a plot of land on which there are ulayat rights of a certain customary law community. Ulayat rights are authorities, which according to customary law, are owned by the customary law community over certain areas which are the environment of their citizens, where this authority allows the community to take advantage of natural resources, including land, in the area for their survival. The community and resources in question have a hereditary and inward relationship between the customary law community and the area concerned.

In customary rights, there are several characteristics that distinguish it from other rights, namely:

1. Only the legal association of the villagers themselves and their residents. Those who have the right to freely use the illegal lands in their territory.

2. Outsiders may only use the land with the permission of the ruler of the legal association.

3. Members of a legal association may take advantage of the territory of ancient rights provided that it is only for their own families.

4. The legal community is responsible for everything that happens in its territory.

5. Primitive rights cannot be released, transferred, exiled.

6. Ulayat rights include land that has been cultivated, which is covered by individual rights (Muhammad, 1983: 116).

In the application process customary rights have a system, namely: The burial system is joint ownership with the division of the period of arable land; Matokgalengjelirwong is cultivated land divided into several fixed fields; Matokgalengmatokwong is a farmer with changing parts and some parts but the land is controlled for the rest of his life; Land can be inherited along with the acquisition of land that is controlled for life (Wignjodipoero, 1984: 19).

The customary land of the customary community is a form of customary community legal territory whose ownership is controlled by a group of tribes who inhabit a certain area. As in MuaraEnim district, South Sumatra Province in one of the villages, namely Paya Angus village. In this village there are customary and communal rights. Paya Angus village still applies the distribution of customary land rights to the local village community. Each head of the family received a communal land distribution.

Paya Angus Village is located in the sub-district of Voorame, MuaraEnim Regency, South Sumatra Province. The people of Paya Angus 
village still use customary law in determining their customary land so that the people there get their rights in land tenure. The land is used for the cultivation of rubber and oil palm plantations because the livelihoods of these residents are rubber and oil palm farmers. However, in practice, is it true that all communities have obtained their Ulayat rights in accordance with customary law which is the main source in the formulation of national land laws.

The distribution of customary land to ulayat rights in the payaangus village is given to each head of the family for the indigenous people of the local village. The communal land is used by the village community for gardening. On a daily basis, the average villager works as a farmer, some also plant rubber and oil palm. There are residents who cultivate their own rubber gardens by cultivating and tapping the rubber themselves or by other people. For oil palm plantations, there are companies involved in managing it, of course, with a profit sharing system between the villagers and the company.

In the existence of ulayat rights, which initially were only land rights granted to the waganya, to further legalize the land certificate, residents of Paya Angus Village already have an increase in proof of ownership of the ulayat land into the form of land certificates in the form of property rights, This is done because there are many Paya Angus villagers who understand the value of proof of ownership of land rights, from the level of an ordinary proof of ownership written on a piece of paper and legalized by the village head, village head and sub-district head, then they legalize the land certificate again to become form of certificate and registered with the land office of MuaraEnim Regency.

The understanding and views of indigenous peoples on land, especially the Paya Angus Village Community, are supported in the sense of Customary Land Law contained in the Basic Agrarian Law (UUPA), which regulates the control of Land Rights over the Ulayat Rights of the Panya Village Community, so that the rights to customary land can be fought for through the right legal channels if there are rights to customary land whose acquisition is not in accordance with the rights of the customary community.

The rights to land in article 4 of the Basic Agrarian Law are individual rights, all of which are directly or indirectly derived from the Rights of the Nation, which are mentioned in articles 16 and 53, namely:

1. Land rights that are primary: namely rights to land originating from the State, namely in the form of: Ownership Rights, Business Use Rights, Building Use Rights, and Use Rights

2. Land rights that are secondary in nature: namely land rights originating from other parties, namely in the form of Building Use Rights over land and Use Rights, which are granted by the land owner over their land, Pawning Rights, Production Sharing Business Rights which are agreements for yield, Right to Pass, Right to Rent on agricultural land.

3. Waqf, namely property rights that have been donated by article 49

4. Security rights over land which are called "Mortgage Rights" in articles 25, 33, 39 and 51 (Santoso, 2012: 91).

The distribution of customary rights in the village of Paya Angus is carried out by the village head where only the original inhabitants of the village can obtain their ulayat rights, to be used and cultivated by 
themselves, because in essence the customary rights are given to local residents and to be cultivated by the paya angus residents. as an effort to make ends meet. These customary land rights are distributed to all Payangus villagers equally, each obtaining $2 \mathrm{Ha}$ of land and is used for the needs of each resident in meeting their needs (Interview with Cik Den, 2020, June 26).

\section{A. Forms of Legal Protection for the Land Rights of the Payaangus Village Community in MuaraEnim Regency.}

A legal community or legal association is an organized human entity, resides in a certain area, has rulers and has "their own tangible and intangible assets", where the members of each unit experience life in society as a natural thing according to nature and not one of the members has the thought or inclination to let the bond that has grown or to leave it, in the sense of breaking away from it for good. "The state has a concept of rights. Indigenous communities also have the concept of the Rights and Living Areas of Indigenous Peoples.

In customary law, between the legal community as a legal entity and the land they occupy, there is a very close relationship, namely a relationship that is rooted in a magical religious view. This relationship causes the legal community to obtain the right to control the land, utilize the land, and collect the produce from the plants that live on the customary land..

The definition of legal protection for the people according to Philipus M. Hadjon, which in the Dutch-language formula reads "rechtsbesherming van de burgers tegen de overhead" and in the English formulation it reads "Legal Protection of the individual in relation to acts of administrative authorities" (philipus M. Hardjon 1978) This means that legal protection for the people is related to an action by the government which can commit arbitrary acts or exceed the existing authority over it. Legal protection for the people who hold customary rights is inseparable from the conception of article 18 paragraph (2) of the 1945 Constitution which expressly recognizes and respects the unity of the customary law community and their traditional rights.

To provide protection for citizens who truly have rights to the land, the State regulates it in the Basic Agrarian Law in Article 26 paragraph (1) which states that: "buying and selling, exchanging, giving, giving wills, giving according to customs and other actions intended to transfer property and control shall be regulated by a Government Regulation ". However, the reality is that many lands controlled by customary law communities (ulayat rights) were taken by the government by means of violence.

The customary rights and similar rights of customary law communities are defined as the authority which, according to customary law, has a certain customary law community over a certain area which is the living environment of its citizens to benefit from natural resources, including land in that area, for the continuity of life and life, which arise from external and inner, hereditary and unbroken relationships between the customary law community and the area concerned (Wignyodipuro, 1983).

According to Muktie, A. Fadjar Legal protection is a narrowing of the meaning of protection, in this case only protection by law. Protection provided by law is also related to the existence of rights and obligations, in this case 
those owned by humans as legal subjects in their interactions with fellow humans and their environment. As a legal subject, humans have the right and obligation to take legal action.

Taking over customary rights without the consent of the customary community is a form of violation of human rights as stated in article 6 of Law Number 39 of 1999 concerning Human Rights which reads: "In the context of upholding human rights, differences and needs within indigenous peoples must be considered and protected by law, society, and government ". Ownership of people's land is a human right that is protected by international law and national law. In international law, this property is regulated in the Universal Declaration of Human Rights (UDHR), namely:

1. Article 17 paragraph (1): Everyone has the right to own property either individually or collectively with other people.

2. Article 17 paragraph (2): No one can be confiscated of their property arbitrarily ",

Article 30: Nothing in this declaration can be interpreted as giving a State, group or person the right to engage in activities or take any action aimed at destroying any rights and freedoms set forth in this declaration. "

Article 67 paragraph (1) of Law Number 24 of 2003 concerning Forestry states: "Customary law communities as long as they still exist and are recognized for their existence, have the right to:

1. Collecting forest products to fulfill the daily needs of the indigenous peoples concerned;

2. Carrying out forest management activities based on applicable customary law and not contradicting the Law, and Obtaining empowerment in order to improve their welfare.

Furthermore, in the explanation of article 67 of Law Number 24 of 2003 , states that "as a customary law community, its existence is recognized if according to reality it fulfills the following elements, among others:

1. The community is still in the form of a community (rechsgemeenschap),

2. There are institutions in the form of customary rulers,

3. There is a clear customary law area,

4. There are legal institutions and instruments, especially customary courts that are still adhered to.

They still collect forest products in the surrounding forest area to fulfill their daily needs Basically, the existence of customary rights in the UUPA has been recognized, but the recognition is still followed by certain conditions, namely "existence" and regarding its implementation. Therefore, customary rights can be recognized as long as in reality they still exist. The point is if in areas where customary rights no longer exist, it will not be revived.

In customary law communities, land has a very important meaning, because according to its nature, land is the only property of wealth which, despite experiencing any circumstances, is still in its condition, sometimes even becomes more profitable. Due to the fact, land is the residence of the 
fellowship, gives life to the community, is a place where members of the community who die are buried and is also a place to live for the protection ladies of the fellowship and the spirits of the ancestors of the community (Wignyodipuro; 1983).

For the customary community of Paya Angus village, totaling 434 heads of families, all of them have received their respective customary rights, which is $2 \mathrm{Ha}$ for each head of the family so that no violations have occurred against the ulayat rights of Paya Angus village, and if there are residents who have not got the rights as they should. In the distribution of customary rights, the villagers still receive legal protection that refers to the Basic Agrarian Law and applicable customary law. In Paya Angus village, customary rights are still valid for residents who were originally local villagers but because they work as Civil Servants in other areas which are still in MuaraEnim Regency, they still get their ulayat rights and can still cultivate the communal land in Paya Angus village (Interview with Hamid, 2020, August 6).

Thus it can be concluded that from the explanation above, ulayat rights are not clearly explained about the existence of a legal basis and governing rules, but customary rights are recognized by law and their application refers to the Basic Agrarian Law and applicable customary law.

\section{Conclusion}

From the explanation above, it can be understood that land is the surface of the earth which is one of the objects regulated by Agrarian Law. Land which is regulated by agrarian law is not land in its various aspects, but land from its juridical aspect, which is directly related to land rights which are part of the surface of the earth as regulated in Article 4 paragraph (1) of the Basic Agrarian Law (UUPA). The customary land of the customary community is a form of customary community legal territory whose ownership is controlled by a group of tribes who inhabit a certain area. As in MuaraEnim district, South Sumatra Province in one of the villages, namely Paya Angus village. This village still applies the distribution of customary land to the local village community. Each head of the family received a communal land distribution. The distribution of customary rights in the village of Paya Angus is carried out by the village head where only the original inhabitants of the village can obtain their ulayat rights, to be used and cultivated by themselves, because in essence the customary rights are given to local residents and to be cultivated by the paya angus residents as an effort to make ends meet. This Ulayat land right is distributed to all Payangus villagers evenly, each obtaining $2 \mathrm{Ha}$ of land and used for the needs of each resident to meet their needs.

The form of legal protection for the ulayat rights of the Payaangus village community is that the ulayat rights are not clearly explained about the existence of a legal basis and governing rules, but the customary rights are recognized by law and its application refers to the Basic Agrarian Law and applicable customary law. inPaya Angus Village, for residents of the original village of Paya Angus who already live outside the village because they work as Civil Servants but are still in MuaraEnim Regency, they can 
still manage their ulayat land in Paya Angus village without losing their rights as villagers. AsliPaya Angus as long as the land is still being cultivated or used properly and is still being cultivated by the owner of the customary rights with the knowledge and approval of the Village Head of Paya Angus.

From interviews that have been conducted with the Village Head, Village officials and also five (5) residents who are residents who work as farmers and also as Civil Servants, data is obtained that it is true that in Paya Angus Village, they still apply the Land Rights of the Ulayat that have been distributed. to each head of the family of 2.5 hectares and not only residents who work as farmers who get their rights but also those who work as Civil Servants also get their rights because they are native to the village of Paya Angus.

\section{References}

Arba, M. (2017). Hukum agraria Indonesia. SinarGrafika.

Djuhaendah, Hasan. (1997). Rumah Vertikal Berdasarkan Sistem Strata Title Suatu Alternatif Dalam Pemilikan Rumah Oleh Orang Asing. Majalah Hukum Nasional, BPHN, No.1.

Ginting, Darwin. (2012). Politik hukum agraria terhdap hak ulayat masyarakat hukum adat di Indonesia, Jurnal Hukum dan Pembangunan, $\quad 42(1)$, http://dx.doi.org/10.21143/jhp.vol42.no1.284

Harsono, Boedi. (1999). Hukum agraria Indonesia. Djambatan.

Harsono, Budi. (2008). Pokok-pokok hukum agraria. Djambatan.

Mertokusumo, Soediknno. (1988). Hukum dan Politik Agraria. Karunika.

Mustofa, Bachsan. (1988). Hukum agraria dan perspektif. Remadja Karya.

Muhammad, Bushar. (1983). Pokok-pokok hukum adat. Pradnya Paramita.

Moleong, Lexy. (2004). Metodologi penelitian kualitatif' (ed.). Remaja Rosdakarya.

Santoso, Urip. (2012). Hukum agraria kajian komprehensif. Kencana Prenadamedica Group.

Santoso, Urip. (2010). Hukum agraria dan hak - hak atas tanah. Kencana Prenadamedia Group.

Wignjodipoero, Seorojo. (1984). Pengantar dan asas-asas hukum adat, Gunung Agung.

Yusuf, Muslim Andi. (2016). Kepastian hukum hak masyarakat hukum adat atas tanah dan sumber daya alam, Prosiding Seminar Nasional, 2(1), 675-685. 